\title{
Characteristics of Participants and Satisficing Tendency in Online Surveys Using a Sample Provider ${ }^{1}$
}

\author{
Asako MIURA (Osaka University) ${ }^{2,3}$, Tetsuro KOBAYASHI (City University of Hong Kong)
}

\begin{abstract}
A panel sample provider is a service that acts as an intermediary between a researcher and a survey monitor supplier in a web-based survey, and earns a transaction fee by providing the supplier with information on the survey that the researcher has registered and set up. In this report, we focused on LUCID (https://luc.id/), the world's largest panel sample provider and conducted a simple experimental online survey using LUCID in Japan, the U. S., the U. K., and China and examine participants' tendency to engage in satisficing when they do not pay due attention to the survey and its effect on their tendency to respond to an experimental task of "false consensus effect." The percentage of satisficers who violated the instructions both times was high for both tasks in JP and $\mathrm{CN}$. The effect sizes of one's own choice for satisficers were relatively smaller (though not absolutely small) than those for compliers and converts. These results show both the possibility that satisficing biases experimental results and the possibility that it can be corrected in a more appropriate direction by alerting.
\end{abstract}

\section{What is a panel sample provider?}

A panel sample provider is a service that acts as an intermediary between a researcher and a survey monitor supplier in a web-based survey, and earns a transaction fee by providing the supplier with information on the survey that the researcher has registered and set up. In this report, we focus on LUCID (https://luc.id/), the world's largest panel sample provider ${ }^{4}$, which was founded in 2015 and is rapidly becoming popular in Japan, especially among political scientists, starting around 2020. In the case of LUCID, the aforementioned transaction fee is US\$0.25 per response (as of March 2021), regardless of the rewards for responses or sample size.

The implementer of LUCID links the survey environment built-in Qualtrics to LUCID, sets the sample size, the time required, and reward amount for response cooperation. Up to this point, it is similar to crowdsourcing services. In addition to this, LUCID allows us to set the screening of the target population and the allocation of the sample based on a wide variety of variables, such as demographic attributes. The screening of subjects can be achieved by some international crowdsourcing services (e.g., Amazon Mechanical Turk and Prolific), but it is difficult to obtain a Japanese sample from them. Prolific can provide a representative sample according to age, race, and gender, but it is limited to samples from the U.S. and the U.K. and requires a substantial additional fee .

After a researcher completes these settings and sets the survey to "Live," LUCID releases the information to the companies that supply the survey monitors, and monitors who pass the set screening process respond to the survey on Qualtrics. In the case of sample allocation, the implementer monitors the influx of monitors and adjusts the number of influxes, aiming to achieve the target allocation. The payment to LUCID is the total amount of the rewards and transaction fees based on the number of responses that researcher approves as appropriate data.

\footnotetext{
${ }^{1}$ This work was supported by Grant-in-Aid for Scientific Research $18 \mathrm{H} 01081$ and approved by the Research Ethics Committee of the Graduate School of Human Sciences, Osaka University (Jinko 30-117).

${ }^{2}$ Both authors contributed equally to the development of the study concept and design, and to the data analysis and interpretation. AM drafted the manuscript, and TK provided critical revisions. Both authors approved the final version of the manuscript.

${ }^{3}$ Correspondence concerning this article should be sent to Asako Miura, Department of Human Sciences, Osaka

University(E-mail: asarin@hus.osaka-u.ac.jp / Twitter: @asarin)

${ }^{4}$ https://www.qualtrics.com/jp/press/2019-07-iq-product-update/

${ }^{5}$ Since Prolific does not ensure the representativeness of its registrants to the population, the term "provide a representative sample" here is subject to certain restriction.
} 
Now, for researchers (especially in Japan) who have access to services such as Qualtrics that allow them to set up a survey environment, almost the only advantage of outsourcing data collection to an online survey company, rather than a crowdsourcing service, has been the capability to outsource this quota allocaation. However, using such a panel sample provider may make it possible to conduct the survey at a lower cost. For example, in a survey conducted by the first author in January 2021, it cost 484,000 JPY (4,466.80 USD) to conduct a survey of 1,200 Japanese people, equally allocated by gender and age ${ }^{6}$. The same applies to the comparison with the use of international crowdsourcing services. For example, in a survey conducted by the first author using Prolific in March 2021, it cost 2640.18 GBP (3654.01 USD) to obtain data from 1200 people in the UK and the US, respectively, for rewards of 1.13 GBP (1.56 USD), after setting the sample to ensure representativeness ${ }^{7}$. The survey under the same conditions was conducted by LUCID, the amount paid would be $(1.56+0.25) * 1200=2172.00$ USD. In other words, by using a panel sample provider such as LUCID, researchers may be able to reduce the financial cost of online surveys significantly.

The concern with such relatively inexpensive services has always been "cheap is as good as it gets," i.e., cheapness is linked to poor quality of responses. For example, Aronow et al.(2020) used LUCID to collect data on a large scale from January to July 2020, found that the number of participants who did not respond appropriately to the attention check items increased significantly, and the quality of data obtained from such participants was lower than that of participants who responded appropriately. The quality of responses from participants who responded appropriately to the attention check items also tended to decline. These tendencies are called "satisficing" (Krosnick, Narayan, \& Smith, 1996), which refers to the behavior of participants in responding to a survey in which they seek a satisfactory option rather than the best option without devoting the appropriate attentional resources to the survey.

In this paper, we conduct a simple experimental online survey using LUCID and examine participants' tendency to engage in satisficing when they do not pay due attention to the survey and its effect on their tendency to respond to the experimental task. In our previous studies, we have shown that participants' Satisficing can damage data related to the issues that researchers want to examine (e.g., Miura \& Kobayashi, 2016, 2019).

\section{Method}

\subsection{Overview}

We conducted an experimental online survey in Japan, the U. S., the U. K., and China. The experiment was designed based on Miura \& Kobayashi (2016), which includes IMC items (Instructional Manipulation Check; items aimed at checking how much attention participants pay to the survey). In the Miura \& Kobayashi (2016), the IMC item which aimed at checking whether participants skipped relatively large texts such as instructions and scenarios was placed at the beginning of the survey and the following two stages were set. First, the first IMC item is given. For participants who do not respond appropriately, the same IMC items will be presented again with an emphasis on the points that they should pay attention to. Following these stages, the participants are asked to respond to the experimental task. The participants' satisficing tendency is classified according to the pattern of their responses to the IMC items as follows: Compliers (participants who answered the first time appropriately), converts (participants who answered the first time inappropriately and answered the second time appropriately), and satisficers (participants who answered both times inappropriately).

Miura \& Kobayashi (2016) reported that, in an experimental task in which participants were asked to read a scenario about a certain person presented after the IMC items and were asked to rate their impressions, results of compliers supported the hypothesis derived from the theory, while those of Satisficers did not

\footnotetext{
${ }^{6}$ The prices offered by the survey companies vary greatly from company to company and may also vary greatly through price negotiations, so this is just an example.

${ }^{7}$ Without the setting to ensure the representativeness of the sample, the amount paid was 1808.00 GBP (2502.27 USD).
} 
support the hypothesis, probably due to skipping the scenario. The results of converts were relatively close to those of compliers. In other words, the results suggest both that satisficing may damage the experimental results and that it may be possible to correct them in a more appropriate direction by alerting the participants.

In this study, we will conduct an experimental online survey in the same way as Miura \& Kobayashi (2016), but with two differences: First, we will prepare two types of IMC items rather than one. The second difference is that we will use an experimental task that is simpler and for which the reproducibility of the results has been robustly confirmed. The distribution of the satisficing tendency and its effect on the responses to the experimental task will be examined.

\subsection{Target participants and implementation period}

We used LUCID to conduct a total of seven surveys in the four countries. In China(CN), only one survey was conducted with the sample size set to 800, and only the first survey in Japan(JP) was allocated equally to gender. In the other surveys, no allocation was set. The target age range was 18-70 years old. In Japan, the same survey was also conducted using a crowdsourcing service (CrowdWorks, Inc.) for comparison between the sample provider and the crowdsourcing service (hereafter JP.CW). The time required to complete the survey was estimated to be about 2 minutes, and the fee was set at US $\$ 0.40$ for all surveys.

\subsection{Survey Items}

\subsubsection{IMC items for attention check}

Two types of IMC items for attention check were prepared. The IMC-A is based on Aronow et al.(2020). The IMC-B is the one used by the authors in their recent study. Participants are randomly assigned to one of the two types of items. In both types of items, participants are asked to read the questions carefully and are given specific instructions on what to answer. The detailed contents of the items are shown in Figure 1 and Figure 2. Participants who failed to answer the questions properly the first time (i.e., violated the instructions) were presented with the same IMC items again (only the second question in IMC-A). In this case, a message in red was added to the first line to encourage the participants to read the text carefully again.

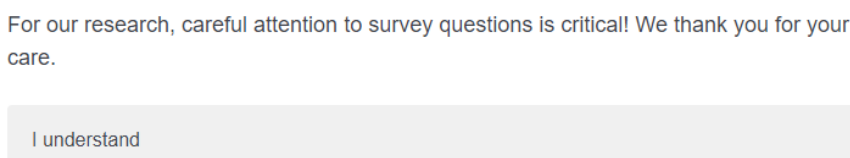




\section{Working papei}

Figure 1 IMC-A (US version), with a page break between the first and second questions.

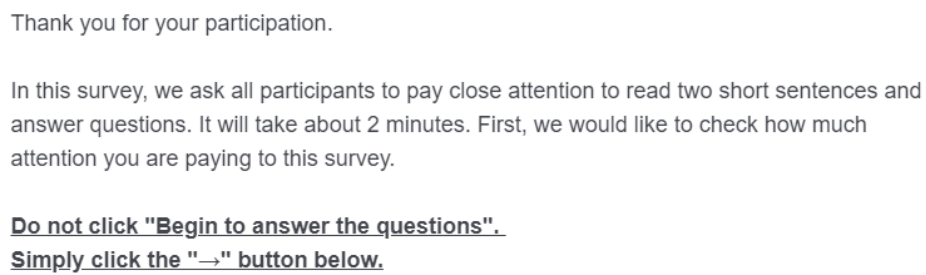

Figure 2 IMC-B (US version)

\subsubsection{Experimental tasks}

One of the purposes of this study is to assess as accurately as possible how satisficing affects respones to the subsequent experimental task. For this purpose, it is necessary to choose an experimental task that verifies robust phenomena as a follow-up to the attentional confirmation. Specifically, data from participants who read the presented stimuli (text, images, etc.) with sufficient attention should be highly reproducible, i.e., the variance of the dependent variable measured under the same conditions is small and the difference between conditions is large (i.e., the effect size of the factor is large), regardless of individuals or attributes.

Therefore, we selected an experimental task to demonstrate the false consensus effect (FCE; Ross, Greene, and House (1977)) from the global multi-laboratory reproducibility verification project ManyLabs2 (Klein et al., 2018). Ross et al. (1977) asked participants to read a scenario describing a situation in which they had to choose between two alternatives, and asked them to estimate what percentage of people would choose each option and then to make their own choice. In ManyLabs2 (Klein et al., 2018), the two scenarios (Supermarket story and Traffic ticket story) that produced significant and strong FCEs in the Ross et al. (1977) by the paper-pencil survey were selected and a web experiment was conducted using almost the same procedure. In the replication project, FCEs were found for both scenarios as in Ross et al. (1977), and the effect sizes were similar and relatively large. Differences by sample attribute, such as whether the sample was WEIRD (Western, Educated, Industrialized, Rich, and Democratic) or not, and by the environment, such as whether a laboratory experiment or an online experiment, were not significant. For these reasons, we decided to use this experimental task, and decided to conduct measurements using the materials used in ManyLabs2. However, unlike ManyLabs2, in which each of the two scenarios was measured together with many other experimental tasks (i.e., one participant answered for only one scenario), both scenarios were presented in a randomized order, and participants were asked to answer the two following two questions in the fixed order. The scenarios and the questions are shown in Table 1.

If participants do not read through the scenario text sufficiently to estimate the choice rate of others or to make their own choice, it is expected that no FCE will occur or the association between the two will be weaker. 
Table 1 FCE scenario and two questions (Engligh version)

\begin{tabular}{|c|c|c|}
\hline Scenario & $\begin{array}{l}\text { Question 1: Estimating the } \\
\text { choice rate }\end{array}$ & $\begin{array}{l}\text { Question 2: Own } \\
\text { choice }\end{array}$ \\
\hline $\begin{array}{l}\text { Supermarket story } \\
\text { As you are leaving your neighborhood supermarket a } \\
\text { man in a business suit asks you whether you like } \\
\text { shopping in that store. You reply quite honestly that } \\
\text { you do like shopping there and indicate that in addition } \\
\text { to being close to your home the supermarket seems to } \\
\text { have very good meats and produce at reasonably low } \\
\text { prices. The man then reveals that a videotape crew has } \\
\text { filmed your comments and asks you to sign a release } \\
\text { allowing them to use the unedited film for a TV } \\
\text { commercial that the supermarket chain is preparing. }\end{array}$ & $\begin{array}{l}\text { What } \% \text { of your peers do you } \\
\text { estimate would sign the release? } \\
\text { /What } \% \text { would refuse to sign it? } \\
\text { Please answer the questions so } \\
\text { that the total will be } 100 \% \text {. }\end{array}$ & $\begin{array}{l}\text { Would you sign the } \\
\text { release or refuse to sign } \\
\text { it? } \\
\text { Sign the release } \\
\text { agreement / Refuse to } \\
\text { sign the release } \\
\text { agreement }\end{array}$ \\
\hline $\begin{array}{l}\text { Traffic ticket story } \\
\text { While driving through a rural area near your home you } \\
\text { are stopped by a county police officer who informs you } \\
\text { that you have been clocked (with radar) at } 38 \text { miles per } \\
\text { hour in a } 25 \text {-mph zone. You believe this information to } \\
\text { be accurate. After the policeman leaves, you inspect } \\
\text { your citation and find that the details on the summons } \\
\text { regarding weather, visibility, time, and location of } \\
\text { violation are highly inaccurate. The citation informs } \\
\text { you that you may either pay an } \$ 80 \text { fine by mail } \\
\text { without appearing in court or you must appear in } \\
\text { municipal court within the next two weeks to contest } \\
\text { the charge. }\end{array}$ & $\begin{array}{l}\text { What } \% \text { of your peers do you } \\
\text { estimate would pay the } \$ 80 \text { fine } \\
\text { by mail? / What } \% \text { would go to } \\
\text { court to contest the charge? } \\
\text { Please answer the questions so } \\
\text { that the total will be } 100 \% \text {. }\end{array}$ & $\begin{array}{l}\text { Would you pay the } \$ 80 \\
\text { fine by mail or appear in } \\
\text { court? } \\
\text { Pay the } \$ 80 \text { fine by mail / } \\
\text { Appear in court }\end{array}$ \\
\hline
\end{tabular}

\subsubsection{Demographic Variables}

After the experimental task, the participants were asked their gender, age, nationality, and native language. In China, they were also asked about their education and annual household income.

\subsubsection{Multilingualization Procedures}

For all items except IMC-B, the original material was in English, which was translated into Japanese and Simplified Chinese. For IMC-B, the original material was in Japanese, and the English version was translated by the first author and corrected by a native English speaker, and the Simplified Chinese version was translated by the first author using DeepL and corrected by a native Chinese speaker.

A preview of the questionnaire for each country can be viewed at the following URL: Qualtrics automatically records the start and end times of responses and the time of data recording (both in minutes). In this survey, the IP address and location (latitude and longitude) of each participant, as well as information about the responding device (OS, browser type, version, language setting, and screen resolution) were recorded as meta-information. However, the aggregate results of these data are not included in this report, so please refer to the open data.

JP:

https://osakashakaishinri.qualtrics.com/jfe/preview/SV 9nVEe7LwP66CXVs?Q CHL=preview\&Q SurveyV $\underline{\text { ersionID }=\text { current }}$ 
JP. CW:

https://osakashakaishinri.qualtrics.com/jfe/preview/SV_3PZUjzVdLpyGEmy?Q_CHL=preview\&Q_SurveyV ersionID=current

US:

https://osakashakaishinri.qualtrics.com/jfe/preview/SV bEJzUrIt7SNnuUC?Q CHL=preview\&Q SurveyVer sionID=current

UK:

https://osakashakaishinri.qualtrics.com/jfe/preview/SV_6h4q709Qpgv4Eyq?Q_CHL=preview\&Q_SurveyVer $\underline{\text { sionID }=\text { current }}$

$\mathrm{CN}$ :

https://osakashakaishinri.qualtrics.com/jfe/preview/SV 6zdcoXCvC2vhwdU?Q CHL=preview\&Q SurveyVe $\underline{\text { rsionID }=\text { current }}$

\section{Results and discussion}

\subsection{Demographic variables}

Table 2 summarizes the eight surveys by target country (Japan by survey medium) and calculates the descriptive statistics of the demographic variables.

Table 2 Descriptive Statistics of Participants' Demographic Variables

\begin{tabular}{l|cccccc}
\hline $\begin{array}{l}\text { Target } \\
\text { country }\end{array}$ & $\begin{array}{c}\text { Number of } \\
\text { responses }\end{array}$ & $\begin{array}{c}\text { Number of valid } \\
\text { responses }(\%)\end{array}$ & $\begin{array}{c}\text { Gender } \\
(\text { Male })\end{array}$ & $\begin{array}{c}\text { Mean age } \\
(S D)^{* 1}\end{array}$ & $\begin{array}{c}\text { Nationality } \\
\text { (target country) }\end{array}$ & $\begin{array}{c}\text { Native language } \\
\text { (target language) }\end{array}$ \\
\hline JP & 938 & $872(93.0 \%)$ & $52.3 \% \%^{* 2}$ & $44.1(14.20)$ & 98.7 & 98.6 \\
JP.CW & 512 & $317\left(61.9 \%^{* 3}\right)$ & 41.0 & $39.5(9.98)$ & 100.0 & 100.0 \\
US & 859 & $805(93.7 \%)$ & 39.5 & $36.8(12.52)$ & 97.6 & 97.3 \\
UK & 846 & $808(95.5 \%)$ & 41.8 & $35.3(11.90)$ & 96.8 & 96.7 \\
CN & 924 & $847(91.7 \%)$ & 48.8 & $31.1(8.87)$ & 98.5 & 99.3 \\
\hline
\end{tabular}

${ }^{{ }^{1}}$ : Samples whose answer of age did not fall within the range of 18-70 years were excluded; ${ }^{* 2:} 50.7 \%$ for the first round (equal gender assignment), 53.7\% for the second round; ${ }^{* 3}$ : A significant number of participants left the survey not only during the survey but also due to technical problems during their responses.

\subsection{Satisficing tendency}

Table 3 shows the distribution of satisficing tendency by country (Japan by survey medium). Comparing IMC-A and IMC-B, the first instruction violation rate is slightly higher (i.e., fewer compliers) in JP and US, but almost the same in UK and CN. The percentage of satisficers who violated the instructions both times was high for both tasks in JP and CN, while the difference between the tasks was slightly larger in the US and UK. It is also noteworthy that among the participants from the crowdsourcing service in Japan (JP.CW), there are a large number of compliers and very few satisficers. Such a difference in the satisficing tendency between the sources of sample is consistent with Miura and Kobayashi(2016). 
Table 3 Frequency distribution of satisficing tendency

\begin{tabular}{l|cc|cc|cc}
\hline \multirow{2}{*}{$\begin{array}{l}\text { Target } \\
\text { country }\end{array}$} & \multicolumn{2}{|c|}{ Compliers } & \multicolumn{2}{c}{ Converts } & \multicolumn{2}{c}{ Satisficers } \\
\hline JP & IMC-A & IMC-B & IMC-A & IMC-B & IMC-A & IMC-B \\
JP.CW & 67.0 & 56.9 & $15.1 \%$ & 27.5 & 17.9 & 15.6 \\
US & 96.9 & 85.9 & 1.9 & 11.5 & 1.2 & 2.6 \\
UK & 78.7 & 67.0 & 9.9 & 16.2 & 11.4 & 16.8 \\
CN & 77.8 & 77.7 & 9.0 & 12.8 & 13.3 & 9.6 \\
\hline
\end{tabular}

\subsection{Effect of Satisficing Tendency on FCE}

To examine the effect of satisficing tendency on FCE, we conducted a between-participant three-factor analysis of variance for each of the two scenarios, with the choice rate estimation as a dependent variable, and their own choice, satisficing tendency, and the country as independent variables. A model including the main effects of each of the three factors and simple/second-order interactions was examined. Results of the ANOVAs are shown in Table 4 and Table 5.

Table 4 Result of ANOVA for supermarket story

\begin{tabular}{l|cccccc}
\hline & Partial $^{\eta 2}$ & $95 \% C I$ & $F$ value & $d f 1$ & $d f 2$ & $p$-value \\
\hline A: Self-choice & .116 & $.096, .136$ & 434.943 & 1 & 3305 & .000 \\
\hline B: Satisficing tendency & .001 & $.000, .004$ & 1.699 & 2 & 3305 & .183 \\
\hline $\mathrm{C}:$ Target country & .007 & $.002, .013$ & 7.595 & 3 & 3305 & .000 \\
\hline $\mathrm{A} * \mathrm{~B}$ & .007 & $.003, .014$ & 12.486 & 2 & 3305 & .000 \\
\hline $\mathrm{A} * \mathrm{C}$ & .006 & $.001, .011$ & 6.518 & 3 & 3305 & .000 \\
\hline $\mathrm{B} * \mathrm{C}$ & .003 & $.000, .006$ & 1.650 & 6 & 3305 & .129 \\
\hline $\mathrm{A} * \mathrm{~B} * \mathrm{C}$ & .002 & $.000, .004$ & 0.973 & 6 & 3305 & .442 \\
\hline
\end{tabular}


Table 5 Result of ANOVA for traffic ticket story

\begin{tabular}{l|cccccc}
\hline & Partial $\eta^{2}$ & $95 \% C I$ & $F$ value & $d f 1$ & $d f 2$ & $p$-value \\
\hline A: Self-choice & .118 & $.098, .138$ & 442.893 & 1 & 3300 & .000 \\
B: Satisficing tendency & .002 & $.000, .006$ & 3.994 & 2 & 3300 & .019 \\
C: Target country & .014 & $.007, .022$ & 15.600 & 3 & 3300 & .000 \\
A*B & .010 & $.004, .017$ & 16.180 & 2 & 3300 & .000 \\
A*C & .002 & $.000, .006$ & 2.739 & 3 & 3300 & .042 \\
$\mathrm{~B} * \mathrm{C}$ & .002 & $.000, .004$ & 1.113 & 6 & 3300 & .352 \\
$\mathrm{~A} * \mathrm{~B} * \mathrm{C}$ & .002 & $.000, .003$ & 0.920 & 6 & 3300 & .479 \\
\hline
\end{tabular}

The main effect of self-choice is significant in both tasks: as in ManyLabs2, a Welch test of the difference in means between the self-choice conditions shows that the Supermarket story (the dependent variable is an estimate of the "sign" selection rate) is $65.1 \%$ in "sign" self-choice, $35.0 \%$ in "refuse to sign" self-choice, $t(3011.30)=36.14, d=1.28,95 \% C I=[1.20-1.35]$, the Traffic ticket story (dependent variable is the estimated "pay a fine" selection rate) is $68.7 \%$ in "pay a fine" self-choice, $38.2 \%$ in "appear in court" selfchoice, $t(2413.650)=1052.61, d=1.20,95 \% C I=[1.12$ - 1.27], indicating that, as in Ross et al. (1977) and Klein et al. (2018), the overall FCE was robust.

The main interest of this report is whether the effect of one's own choice differs by satisficing tendency and whether it differs by country. The interaction effect of own choice and satisficing tendency $(A * B$ in the tables) was significant for both tasks, but the second-order interaction effect was not significant and did not differ by country. The means for each satisficing tendency are shown in Figure 3, and the box plots are shown in Figure 4.

While there was no difference in the significance test of the simple main effect among the satisficing tendencies, the effect sizes $d$ were smaller for compliers, converts, and satisficers, in that order: $1.74,1.22$, and 0.72 for the supermarket scenario, and 1.73, 1.20, and 0.67 for the traffic ticket scenario. In particular, the effect sizes for satisficers were relatively smaller (though not absolutely small) than those for the other two groups. The results of this study show both the possibility that satisficing biases experimental results and the possibility that it can be corrected in a more appropriate direction by alerting, as pointed out by Miura \& Kobayashi (2016). 

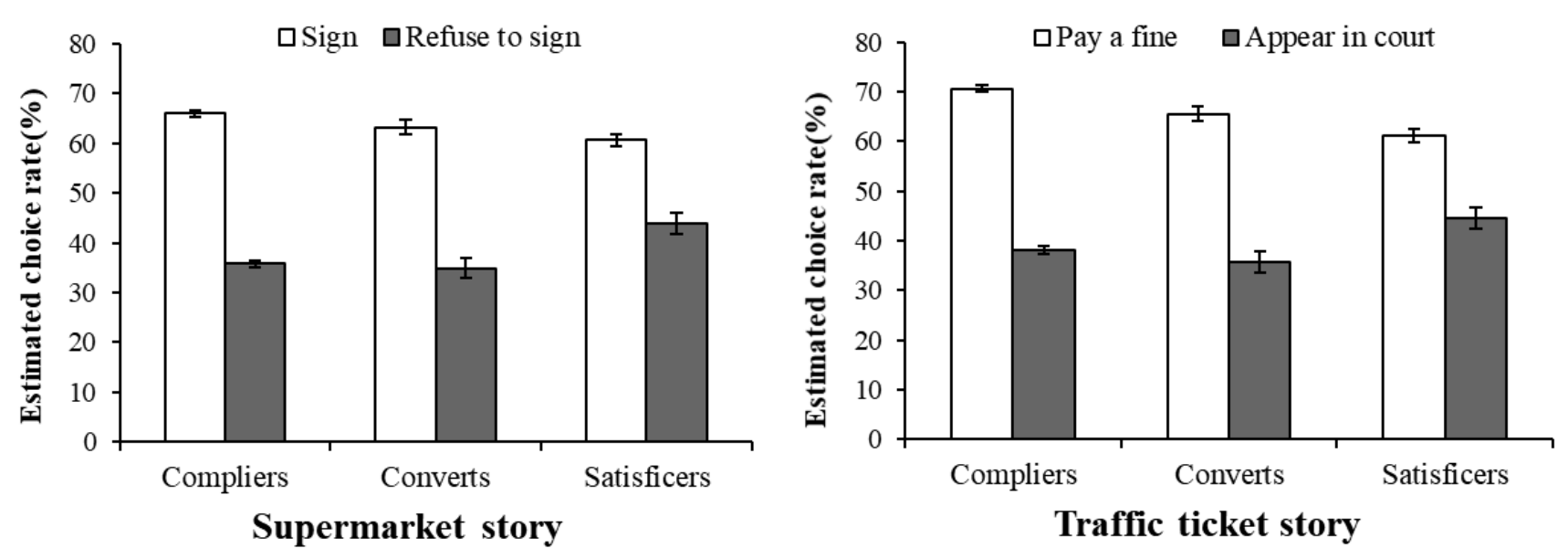

Figure 3 Mean value of estimated choice rates by self-choice and satisficing tendency (error bars are $S E$ )
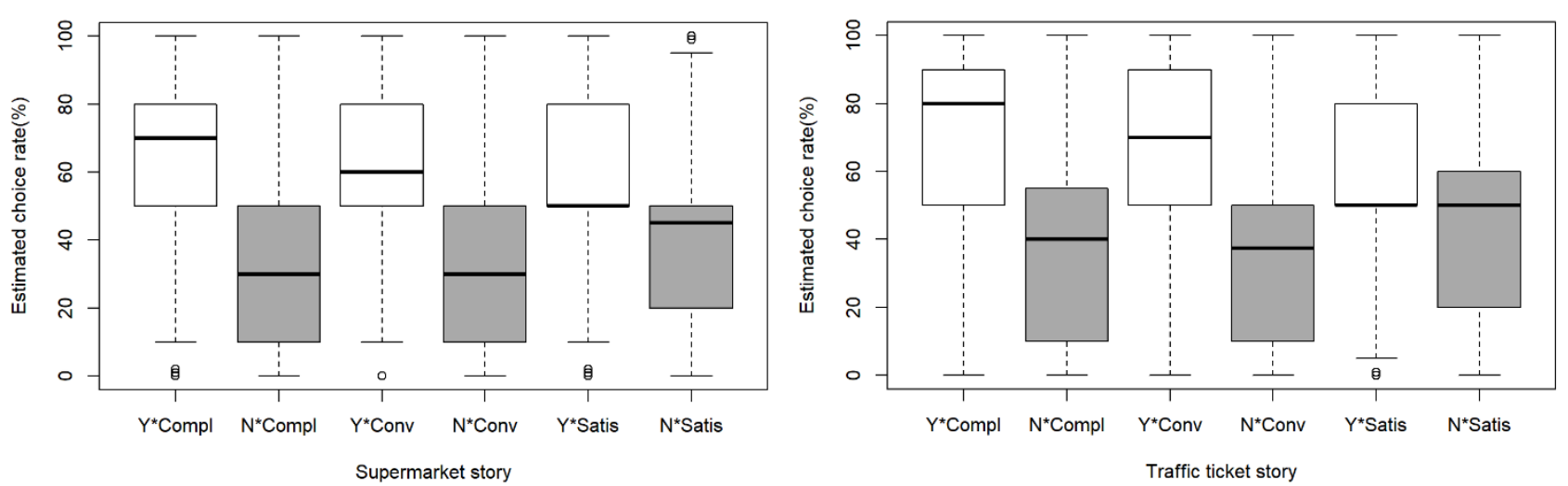

Figure 4 Box-and-whisker plot of estimated choice rates by self-choice and satisficing tendency (Y is "sign" or "pay a fine")

\subsection{Supplement: Verifying the Respondent IP Address}

One of the recent problems in conducting surveys using crowdsourcing services is the use of VPS (Virtual Private Server) to access the survey from outside the target country. In the case of Amazon Mechanical Turk, it is pointed out that the number of responses from outside the US to the US-only survey by VPS already existed in the spring of 2015, and rapidly increased from the summer to the fall of 2018, accounting for about $20 \%$ of the responses (Kennedy et al., 2020). In the case of a survey targeting people in a specific country, such responses would be fraudulent, but it is difficult to remove them by using attention check items. Therefore, only for the US data, we detected the corresponding accesses using the online application IPlookup(https://rkennedy.shinyapps.io/IPlookup), an online application provided by Waggoner \& Kennedy, \& Clifford (2019), for the IP addresses obtained during the Qualtrics response. Only one out of 806 accesses was determined to be VPS. Since the application is limited to the United States, the situation in other countries is not known, but it is unlikely to cause problems, unlike pointed out by Kennedy et al (2020), at least for now.

\section{Open data}

The codebooks and data for the surveys collected and analyzed in this report are available for download at https://osf.io/bxtru/. 


\section{Conflict of interest}

There are no conflicts of interest related to this paper that should be disclosed.

\section{References}

1) Aronow, P. M., Kalla, J., Orr, L., \& Ternovski, J. (2020, September 15). Evidence of Rising Rates of Inattentiveness on Lucid in 2020. SocArXiv Papers. doi: 10.31235/osf.io/8sbe4

2) Kennedy, R., Clifford, S., Burleigh, T., Waggoner, P. D., Jewell, R., \& Winter, N. J. (2020). The shape of and solutions to the MTurk quality crisis. Political Science Research and Methods, 8(4), 614-629. doi: $10.1017 / \mathrm{psrm} .2020 .6$

3) Klein, R. A., Vianello, M., Hasselman, F., Adams, B. G., Adams Jr, R. B., Alper, S., ... \& Sowden, W. (2018). Many Labs 2: Investigating variation in replicability across samples and settings. Advances in Methods and Practices in Psychological Science, 1(4), 443-490. doi: 10.1177/2515245918810225

4) Krosnick, J. A., Narayan, S., \& Smith, W. R. (1996). Satisficing in surveys: Initial evidence. New directions for evaluation, 1996(70), 29-44. doi: 10.1002/ev.1033

5) Miura, A., \& Kobayashi, T. (2016). Survey satisficing inflates stereotypical responses in online experiment: The case of immigration study. Frontiers in psychology, 7, 1563. doi: 10.3389/fpsyg.2016.01563

6) Miura, M. and Kobayashi, T. (2016). To say, or not to say "Good-bye, Mr/Ms online survey panels." Journal of Media, Information and Communication, 1, 27-42. (In Japanese with English abstract)

7) Miura, A., \& Kobayashi, T. (2019). Survey satisficing biases the estimation of moderation effects. Japanese Psychological Research, 61(3), 204-210. doi: 10.1111/jpr.12223

8) Ross, L., Greene, D., House, P. (1977). The "false consensus effect": An egocentric bias in social perception and attribution processes. Journal of Experimental Social Psychology, 13(3), 279-301. doi:10.1016/0022-1031(77)90049-X

9) Waggoner et al., (2019). Detecting Fraud in Online Surveys by Tracing, Scoring, and Visualizing IP Addresses. Journal of Open Source Software, 4(37), 1285. doi: 10.21105/joss.01285 


\section{パネルサンプルプロバイダーを利用した Web 調査の回答者の特徵と Satisficing の現状 ${ }^{1}$}

三浦麻子 (大阪大学 $)^{2,3}$. 小林哲郎 (香港城市大学)

\section{1. パネルサンプルプロバイダーとは}

パネルサンプルプロバイダーとは, Web 調査において, 実施者(例えば, 研究者) と調査モニター供給会 社の仲立ちとなり, 実施者が登録・設定した調査の情報を供給会社に提供することで取引手数料を得るサ ービスのことである.

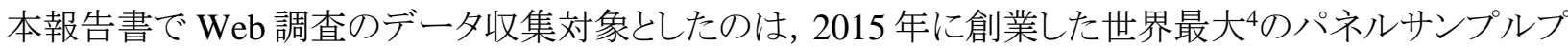
ロバイダーLUCID(https://luc.id/)である. 日本では, 2020 年頃から政治学者を中心に急速に普及しつつあ る. LUCIDの場合, 前述した取引手数料は, 調查謝礼やサンプルサイズにかかわらず, 回答 1 件あたり 0.25 米ドルである (2021 年 3 月現在).

LUCID を利用する実施者は, Qualtrics で構築した調査環境をLUCID とリンクさせ, サンプルサイズ, 所 要時間, 回答協力に対する謝金額などを設定する.ここまではクラウドソーシングサービスと類似している. これに加えて, LUCID では, 人口統計学的属性をはじめとする非常に多様な手がかりに基づいて, 対象者 のスクリーニングとサンプルの割り付けを設定することができる. 対象者のスクリーニングは, 海外のクラウドソ ーシングサービス(例えば Amazon Mechanical Turk や Prolific) でも実現可能だが，日本人サンプルを得る ことは難しい. また, Prolific では年代, 人種, 性別の人口比に合わせて代表性の確保された割り付けを行う ことが可能だが, アメリカとイギリスのサンプルに限られているし, かなりの追加料金が必要となる.

実施者がこれらの諸設定を終えて調査を開始状態(Live)にすると, LUCID はその情報を調査モニター供 給会社にむけて公開し, 条件が折り合うと判断した会社からモニターが流入し, 設定したスクリーニングを通 過したモニターが, Qualtrics 上で調査に回答する. サンプルの割り付けを行った場合は, 実施者自身がモ ニターの流入状況を監視しながら流入数の調整を行い, 自らが目標とした割り付けの達成を目指すことにな る. LUCID に支払うのは, 実施者が適切なデータであると承認した回答数に応じた謝金額と取引手数料の 合計金額である.

さて, Qualtrics など調査環境を構築できるサービスを利用できる(特に, 日本の)研究者にとって, クラウド ソーシングサービスではなく, 調査会社にデータ収集を委託することのほとんど唯一の归性, このサンプ ル割り付けを委託できることにあった. しかし, 研究者側がその人的コストを払うことが条件にはなるものの, パネルサンプルプロバイダーを利用すればより安価で調査が実施できる可能性がある. 例えば, 第 1 著者 が 2021 年 1 月にある調査会社で実施した調査では, 日本人を対象に, 性別と年代を均等割り付けして

\footnotetext{
${ }^{1}$ 本研究は科研費 $18 \mathrm{H} 01081$ による補助を受け, 大阪大学大学院人間科学研究科研究倫理委員会の承認 (人行 $30-$ 117)を受けて行われた.

2 著者連絡先:E-mail: asarin@hus.osaka-u.ac.jp / Twitter: @asarin

3 両著者は, 研究のコンセプトやデザインの策定, データの解析および解釈に等しく貢献した. 三浦が原稿を作成し, 小林が重要な修正を行った. 両名とも最終版の原稿を承認している.

${ }^{4}$ https://www.qualtrics.com/jp/press/2019-07-iq-product-update/

${ }^{5}$ Prolific の登録者の母集団に対する代表性は確保されていないので, ここでいう「代表性の確保」には一定の留保が \<.
} 
1200 名の調査を実施するのに 484000 円 (4466.80ドル)を要した ${ }^{6}$. 海外のクラウドソーシングサービスを利 用する場合との比較も同様である. 例えば, 本報告の第 1 著者が 2021 年 3 月に Prolific で実施した調査で は, サンプルの代表性を確保する設定をした上で, 謝礼 1.13 英ポンド (1.56 米ドル)で英米それぞれ 1200 名のデータを得るのにそれぞれ 2640.18 英ポンド(3654.01 米ドル)を要した7. 同じ条件の調査を LUCID で 実施すると, 支払金額は(1.56+0.25)*1200=2172.00 米ドルとなるはずである. つまり, LUCID のようなパネル サンプルプロバイダーを利用することによって, 研究者は Web 調查の金銭的コストを大幅に削減できる可能 性がある.

こうした相対的に安価なサービスにおいて常に懸念されるのは「安かろう悪かろう」,つまり安価であること と回答の質の低さが連動することである. 例えば, LUCID を利用して 2020 年 1 月から 7 月にかけて大規模 にデータを収集した Aronow et al.(2020)は, 注意確認項目に適切に回答しない参加者が大きく増加し, そう した参加者から得られるデータの質は, 適切に回答した参加者より低いものにとどまっていること, あるいは, 注意確認項目に適切に回答した参加者の回答の質も低下傾向にあると指摘している. このように, 調査回 答に際して, 回答者が調査に際して応分の注意資源を割かずに, 最善の選択肢ではなく満足できる選択肢 を求める行動のことを Satisficing といら(Krosnick, Narayan, \& Smith, 1996).

そこで本報告では, LUCID を利用してごく簡単な実験的 Web 調査を実施し，回答者が調査回答に際し て応分の注意を払わないことによって生じる Satisficing 傾向と, それが事後の実験課題に対する回答傾向 に及ぼす傾向を検討する. 報告者らのこれまでの研究において, 回答者による Satisficing は, 研究者が本 来検証したい課題に関するデータを毀損することが示されている(e.g. Miura \& Kobayashi, 2016, 2019).

\section{2. 方法}

\section{1 概要}

日本・アメリカ・イギリス・中国で, 実験的Web 調査を行った. 実験は, Miura \& Kobayashi (2016)を参考に してデザインした. Miura \& Kobayashi(2016)の調査では, 回答者が調査にどの程度注意を払っているかを 確認するための IMC 項目 (Instructional Manipulation Check; 教示やシナリオなど, 比較的分量の多い文章 の読み飛ばしを確認することを目的とした項目)が冒頭に置かれ，次のような 2 段階が設けられている. ま ず, 1 回目の IMC 項目を呈示する。ここで適切な回答ができなかった参加者には, 注意すべき箇所を強調 した上で同じ IMC を再度提示する. その後, 実験課題に対する回答を求める. 参加者の Satisficing 傾向 は, IMC 項目への回答パターンに応じて, Compliers (1 回目で適切な回答をした参加者), Converts (1 回 目では適切ではない回答をし, 2 回目で適切な回答をした参加者), Satisficers (2 回とも適切ではない回答 をした参加者)に分類する.

Miura \& Kobayashi (2016)では, IMC 項目の後に提示された, ある人物に関するシナリオを読ませて印象 評定を求める実験課題において, Compliers では理論から導出された仮説を支持する結果が得られた一 方, Satisficers では, シナリオを読み飛ばしたことに起因すると思われる, 仮説を支持しない結果が得られ, Converts では比較的 Complier に近い結果が得られたことが報告されている.つまり, Satisficing が実験結 果を毀損する可能性と, 注意喚起を行うことによりそれをより適切な方向に修正できる可能性の両方が示唆 されている.

\footnotetext{
6 調査会社が呈示する価格は会社により大きく異なり, また価格交渉によっても大きく変化する場合があるので, これは あくまでも一例に過ぎない.

7 サンプルの代表性を確保する設定をしなければ 1808.00 英ポンド(2502.27 米ドル)である.
} 
本研究では, Miura \& Kobayashi (2016) と同様の流れの実験的 Web 調査を行うが, 異なる点が 2 つあ る. 1 つは, IMC 項目をよりシンプルなものにした上で 2 種類用意する.もう 1 つは, 事後の実験課題を, より シンプルで結果の再現性が頑健に確認されているものにする. そして, Satisficing 傾向の分布と, Satisficing 傾向が実験課題に対する回答傾向に及ぼす影響を検討する.

\section{2 対象者と実施時期}

LUCID を利用して, 合計 7 回にわたって調査を実施した. JP/US/UK では設定サンプルサイズを 400 と する調査を 2 回実施した. 1 回目調査に回答したモニターは 2 回目調査に回答しないよう設定した. CNで は設定サンプルサイズを 800 とする調査を 1 回だけ実施した. JP で実施した 1 回目のみ, 性別が均等にな るよう割り付けを設定した. 他では割り付けは設定しなかった. 対象年齢は 18-70 歳とした. また, 日本につ いては, 調査媒体間の比較のために, クラウドソーシングサービス(株式会社クラウドワークス)でも調査を実 施した (以下, JP.CW). 回答所要時間は 2 分程度と見込み, 謝金はいずれも 0.40 米ドル相当とした.

\section{3 調査項目}

\subsection{1 注意確認のための IMC 項目}

注意確認のための IMC 項目は, Aronow et al.(2020)を参考にして作成したもの (以下, IMC-A) と, 著者 らが最近の研究で用いているもの（以下，IMC-B）の 2 種類を用意し，回答者をいずれか 1 つにラダムに 割り当てた.いずれも, 調査協力に際して質問を注意深く読んでほしいことを明記した上で, 回答すべき内 容を具体的に指示するものである. 具体的な項目内容は Figure 1 と Figure 2 に示すとおりである. 1 回目に 適切な回答ができなかった(つまり, 指示に違反した) 参加者には, 再度同じ IMC 項目 (IMC-A では 2 問目 のみ)を呈示した. その際は, 1 行目にもう一度文章をよく読むように促すメッセージを赤字で付した. 
最近の人々は非常に多忙なので，多くの人は自分の地域や国で何が起こっているのかを追 う時間がありません．私たちは，人々が質問を読むかどうかをテストしています，これを よく読んだことを示すために，「非常に関心がある」と「かなり関心がある」の両方を選 択してください.

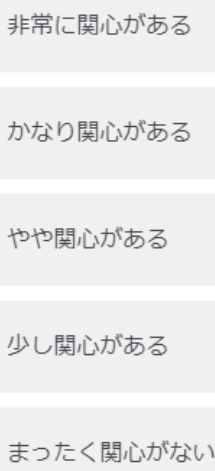

Figure 1 IMC-A (日本語版). 1 問目と 2 問目の間は改ページする.

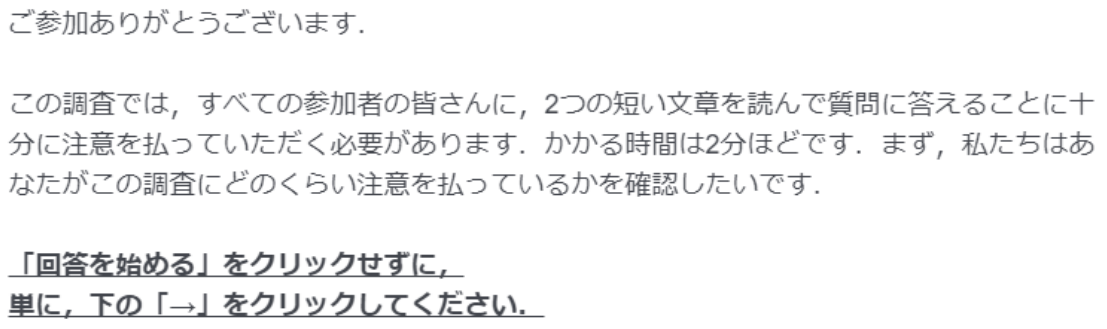

Figure 2 IMC-B (日本語版)

\subsection{2 実験課題}

本研究の目的の一つは, Satisficing 傾向が事後の実験課題に対する回答傾向に及ぼす傾向をなるべく 正確に査定することである. そのためには, 注意確認に後続する実験課題として, 頑健な現象を検証するも 
のを選ぶ必要がある. 具体的には, 呈示する刺激 (文章や画像など)を十分な注意を払って読んだ回答者 によるデータは, 個人や属性を問わず, 同じ条件下で測定された従属変数の分散が小さく条件間の差が大 きい(すなわち, 要因の効果量が大きい), という結果の再現性が高い課題である.

そこで, 世界的なマルチラボ再現性検証プロジェクト ManyLabs2(Klein et al., 2018)から, 偽の合意効果 False consensus effect(以下, FCE)を実証する実験課題(Ross, Greene, and House, 1977)を選択した. FCE と は，自分の判断や意見を一般的なものと見なし，集団内でそれと同じ判断や意見を持つ人の数を相対的に 多く見積もる現象のことである. Ross et al.(1977)は, 回答者に 2 肢からの選択を行うことが必要な場面を記 述したシナリオを読ませた上で, 各選択肢を何パーセント程度の人が選択するかを推定させ, その後, 自身 の選択を行わせる実験デザインとなっている. ManyLabs2(Klein et al., 2018)では, Ross et al.(1977)の実験 (紙筆版)で有意な FCE が得られた 2 つのシナリオ (Supermarket story と Traffic ticket story)について, ほ ぼ同じ手続きで Web 実験が行われた. どちらのシナリオについても Ross et al.(1977)と同じく FCE が認めら れ, 効果量もほぼ同程度で, 比較的大きなものであった. また, WEIRD(Western, Educated, Industrialized, Rich, and Democratic)かどうかというサンプルの属性による差異や, 実験室実験かオンライン実験かといった 環境による差異も有意ではなかった. これらの点で, この実験課題を用いることが適切であると判断し， ManyLabs2 で用いられた素材で測定を行うことにした. ただし，2つのシナリオをそれぞれ他の多数の再現 性検証対象となった実験課題とともに 1 組にして(つまり, ある回答者は FCEについては 1 シナリオのみに ついて)測定していた ManyLabs2 とは異なり, 2 つのシナリオを両方とも, 呈示順序をランダマイズして呈示 し, 2 つの質問に同じ順で回答を求めた. シナリオと 2 つ質問を Table 1 に示す.

回答者がシナリオの文章に十分に目を通さずに他者の選択率の推定や自身の選択を行った場合は， FCEが生じない(両者の関連付けは弱くなる)ことが予想される. 
Table 1 FCE のシナリオと 2つの質問 (日本語版)

\begin{tabular}{|c|c|c|}
\hline シナリオ & 質問 1 : 選択率の推定 & 質問 2: 自身の選択 \\
\hline $\begin{array}{l}\text { Supermarket story } \\
\text { あなたが近所のスーパーマーケットを出ようとしたとこ } \\
\text { ろで, スーツを着た男性が「あなたはこ店で買い物 } \\
\text { をするのが好きですか」と問いかけてきました. あなた } \\
\text { はごく正直にここで買い物するのが好きだ」と答え, } \\
\text { 家に近いことに加えて, そのスーパーの肉の品揃えが } \\
\text { とてもよく, しかも安価で販売しているからだと説明しま } \\
\text { した. 寸ると, その男性は, 撮影隊があなたのコメントを } \\
\text { 録画していたことを明かし, あなたのコメントをそのスー } \\
\text { パーチェーンが準備しているテレビコマーシャルに編 } \\
\text { 集なしで使いたいので, 同意文書にサインしてほし } \\
\text { い, と頼んできました. }\end{array}$ & $\begin{array}{l}\text { 何パーセントくらいの人が，\{使 } \\
\text { 用同意書にサインする/使用を } \\
\text { 拒否する\}と思いますか?（合 } \\
\text { 計が 100\%になるよう回答） }\end{array}$ & サインする/サインしない \\
\hline $\begin{array}{l}\text { Traffic ticket story } \\
\text { あなたが自宅近くの郊外をドライブしていると, 警察官 } \\
\text { に止められました. 警察官によると,レーダーの記録に } \\
\text { よれば, } 40 \text { キロ制限の道路を } 60 \text { キロで走行していた } \\
\text { のだそうです. あなたはその情報は正しいと思ってい } \\
\text { ます.ただ, 警察官が立ち去った後に違反通知書をよ } \\
\text { く見てみると, 違反時の天気や視界, 時刻や場所など } \\
\text { がかなり不正確であることがわかりました. 通知書に } \\
\text { は, 裁判所に出頭せずに藅金 } 1 \text { 万円を郵送で支払う } \\
\text { か, 異議申し立てをするなら } 2 \text { 週間以内に裁判所に } \\
\text { 出頭せよと書かれています. }\end{array}$ & $\begin{array}{l}\text { 何パーセントくらいの人が，\{罰 } \\
\text { 金 } 1 \text { 万円を郵送で支払う/異議 } \\
\text { 申し立てのために裁判所に出 } \\
\text { 頭する\}と思いますか? }\end{array}$ & $\begin{array}{l}\text { 罰金 } 1 \text { 万円を郵送で支 } \\
\text { 払う/裁判所に出頭する }\end{array}$ \\
\hline
\end{tabular}

\section{3 .3 人口統計的変数}

実験課題の後に, 性別, 年齢, 国籍, 母語を尋ねた. 中国では, 学歴と家計年収についても尋ねた.

\subsection{4 多言語化の手続き}

IMC-B 以外の項目は元のマテリアルが英語なので, それを日本語あるいは簡体中国語に翻訳した. 日 本語は第 1 著者が翻訳したものを第 2 著者が確認し, 簡体中国語は第 1 著者が DeepL で翻訳し, 英中マ ルチリンガルの中国語ネイティブスピーカーによる修正を受けた. IMC-B は, 元のマテリアルが日本語で, 英語版は第 1 著者が翻訳し, 英語ネイティブスピーカーによる修正を受けたもの, 簡体中国語は第 1 著者 が DeepLで翻訳し，中国語ネイティブスピーカーによる修正を受けたものを用いた.

各国の調查票のプレビューが以下の URLから参照できる. Qualtrics では, 回答開始・終了時刻およびデ 一タ記録時刻 (いずれも分単位)が自動的に記録される. さらに本調査では, メ夕情報として, 回答者の IP アドレスと位置情報 (緯度・経度), 回答端末に関する情報 $(\mathrm{OS}$, ブラウザの種類・バージョン・言語設定, 画 面解像度)を記録した. ただし,これらの集計結果についてはこの報告には含めないので, オープンデータ をご参照いただきたい. 
JP:

https://osakashakaishinri.qualtrics.com/jfe/preview/SV 9nVEe7LwP66CXVs?Q CHL=preview\&Q SurveyV ersionID $=$ current

\section{JP.CW:}

https://osakashakaishinri.qualtrics.com/jfe/preview/SV_3PZUjzVdLpyGEmy?Q_CHL=preview\&Q_SurveyV ersionID=current

US:

https://osakashakaishinri.qualtrics.com/jfe/preview/SV_bEJzUrIt7SNnuUC?Q_CHL=preview\&Q_SurveyVer $\underline{\text { sionID }=\text { current }}$

$\mathrm{UK}$ :

https://osakashakaishinri.qualtrics.com/jfe/preview/SV_6h4q7O9Qpgv4Eyq?Q_CHL=preview\&Q_SurveyVer sionID=current

$\mathrm{CN}$ :

https://osakashakaishinri.qualtrics.com/jfe/preview/SV_6zdcoXCvC2vhwdU?Q_CHL=preview\&Q_SurveyVe $\underline{\text { rsionID }=\text { current }}$

\section{3. 結果と考察}

\section{1 人口統計的変数}

Table 2 に, 8 つの調査を対象国ごと (日本は媒体別)にまとめ, 回答者の人口統計学的変数の記述統計 を算出したものを示す.

Table 2 回答者の人口統計的変数の記述統計

\begin{tabular}{l|cccccc}
\hline 対象国 & 回答着手数 & 有効回答数 (率) & 性別 (男性) & 平均年齢 $(S D)^{* 1}$ & 国籍(対象国) & 母語(対象国語) \\
\hline JP & 938 & $872(93.0 \%)$ & $52.3 \% \%^{* 2}$ & $44.1(14.20)$ & $98.7 \%$ & $98.6 \%$ \\
JP.CW & 512 & $317\left(61.9 \% \%^{* 3}\right)$ & $41.0 \%$ & $39.5(9.98)$ & $100.0 \%$ & $100.0 \%$ \\
US & 859 & $805(93.7 \%)$ & $39.5 \%$ & $36.8(12.52)$ & $97.6 \%$ & $97.3 \%$ \\
UK & 846 & $808(95.5 \%)$ & $41.8 \%$ & $35.3(11.90)$ & $96.8 \%$ & $96.7 \%$ \\
CN & 924 & $847(91.7 \%)$ & $48.8 \%$ & $31.1(8.87)$ & $98.5 \%$ & $99.3 \%$ \\
\hline
\end{tabular}

${ }^{{ }^{1}}$ : 年齢の回答值が 18-70 歳の範囲にないサンプルは除外した, ${ }^{* 2}: 1$ 回目 (性別均等割り付け設定) $50.7 \%, 2$ 回目 $53.7 \%,{ }^{* 3}$ :回答者の途中離脱だけではなく, 調查実施に際する一時的な不具合によるものが相当数含まれている

\subsection{Satisficing 傾向}

対象国ごと (日本は媒体別)の Satisficing 傾向の度数分布を Table 3 に示す. IMC-A と IMC-B を比較す ると, JP とUS では 1 回目の指示違反率がやや高い(Compliers が少ない)が, UK と CNではほとんど変わ りがない. また, 2 回とも指示に違反した Satisficers の割合は, JP と CN では両課題で高く, US とUK は課 題による差がやや大きい. また特筆すべき点は, 日本のクラウドソーシングサービスの登録者(JP.CW)では Compliers が非常に多く, Satisficers は極めて少ないことである.こうした媒体間の Satisficing 傾向の差は, 三浦・小林(2016)で示されたものと一貫している. 
Table 3 Satisficing 傾向の度数分布

\begin{tabular}{l|cc|cc|cc}
\hline \multirow{2}{*}{ 対象国 } & \multicolumn{2}{|c|}{ Compliers } & \multicolumn{2}{c|}{ Converts } & \multicolumn{2}{c}{ Satisficers } \\
& IMC-A & IMC-B & IMC-A & IMC-B & IMC-A & IMC-B \\
\hline JP & $67.0 \%$ & $56.9 \%$ & $15.1 \%$ & $27.5 \%$ & $17.9 \%$ & $15.6 \%$ \\
JP.CW & $96.9 \%$ & $85.9 \%$ & $1.9 \%$ & $11.5 \%$ & $1.2 \%$ & $2.6 \%$ \\
US & $78.7 \%$ & $67.0 \%$ & $9.9 \%$ & $16.2 \%$ & $11.4 \%$ & $16.8 \%$ \\
UK & $77.8 \%$ & $77.7 \%$ & $9.0 \%$ & $12.8 \%$ & $13.3 \%$ & $9.6 \%$ \\
CN & $71.7 \%$ & $69.1 \%$ & $10.1 \%$ & $13.8 \%$ & $18.3 \%$ & $17.1 \%$ \\
\hline
\end{tabular}

\subsection{Satisficing 傾向が FCE に及ぼす影響}

LUCID を介して調査に協力した回答者を対象として, Satisficing 傾向が FCEに及ぼす影響を検討する ために, 2 つのシナリオごとに, 選択率の推定を従属変数とし, 自身の選択と Satisficing 傾向および対象国 を独立変数とする参加者間 3 要因分散分析を行った. Satisficing 傾向は, 回答者が A, B どちらの IMC 項 目に回答したかによる区別をせずに Compliers, Converts, Satisficers の 3 水準としてコードした. 3 つの要 因それぞれの主効果と単純/2 次の交互作用を含むモデルを検討した. 分散分析表を Table 4 および Table5 に示す.

Table 4 Supermarket story シナリオに関する分散分析結果

\begin{tabular}{l|cccccc}
\hline & 偏 $\eta^{2}$ & $95 \% C I$ & $F$ 值 & $d f 1$ & $d f 2$ & $p$ 值 \\
\hline $\mathrm{A}:$ 自身の選択 & .116 & $.096, .136$ & 434.943 & 1 & 3305 & .000 \\
\hline $\mathrm{B}:$ Satisficing 傾向 & .001 & $.000, .004$ & 1.699 & 2 & 3305 & .183 \\
\hline $\mathrm{C}:$ 対象国 & .007 & $.002, .013$ & 7.595 & 3 & 3305 & .000 \\
\hline $\mathrm{A} * \mathrm{~B}$ & .007 & $.003, .014$ & 12.486 & 2 & 3305 & .000 \\
\hline $\mathrm{A} * \mathrm{C}$ & .006 & $.001, .011$ & 6.518 & 3 & 3305 & .000 \\
\hline $\mathrm{B} * \mathrm{C}$ & .003 & $.000, .006$ & 1.650 & 6 & 3305 & .129 \\
\hline $\mathrm{A} * \mathrm{~B} * \mathrm{C}$ & .002 & $.000, .004$ & 0.973 & 6 & 3305 & .442 \\
\hline
\end{tabular}


Table 5 Traffic ticket story シナリオに関する分散分析結果

\begin{tabular}{l|cccccc}
\hline & 偏 $\eta^{2}$ & $95 \% C I$ & $F$ 值 & $d f 1$ & $d f 2$ & $p$ 值 \\
\hline A: 自身の選択 & .118 & $.098, .138$ & 442.893 & 1 & 3300 & .000 \\
B: Satisficing 傾向 & .002 & $.000, .006$ & 3.994 & 2 & 3300 & .019 \\
C: 対象国 & .014 & $.007, .022$ & 15.600 & 3 & 3300 & .000 \\
A*B & .010 & $.004, .017$ & 16.180 & 2 & 3300 & .000 \\
$\mathrm{~A} * \mathrm{C}$ & .002 & $.000, .006$ & 2.739 & 3 & 3300 & .042 \\
$\mathrm{~B} * \mathrm{C}$ & .002 & $.000, .004$ & 1.113 & 6 & 3300 & .352 \\
$\mathrm{~A} * \mathrm{~B} * \mathrm{C}$ & .002 & $.000, .003$ & 0.920 & 6 & 3300 & .479 \\
\hline
\end{tabular}

両課題において自身の選択の主効果は有意である. ManyLabs2 と同じく, 自身の選択条件間の平均值 の差の Welch 検定を行うと, Supermarket story（従属変数は「サインする」選択率の推定）は, サインする $65.1 \%$, サインしない $35.0 \%, t(3011.30)=36.14, d=1.28,95 \% C I=[1.20-1.35]$, Traffic ticket story (従属変 数は「罰金を支払う」選択率の推定) は, 罰金を支払う $68.73 \%$, 裁判所に出頭する $38.20 \%, t(2413.650)=$ 1052.61 $d=1.20,95 \% C I=[1.12$ - 1.27]であった. Ross et al.(1977)および Klein et al. (2018) と同じく, 全体と しては頑健な FCEが認められたといえる.

本報告の主たる関心の対象は, 自身の選択による影響が Satisficing 傾向によって異なるのから゙うか, お よび, そこに対象国による違いがあるかどうか, である. 自身の選択と Satisficing 傾向は交互作用効果(表の A*B) は両課題ともに有意であったが, 2 次の交互作用効果は有意ではなく, 対象国による違いはなかっ た. そこで, Satisficing 傾向ごとの単純主効果の検定を行ったが, 3 群ともに全体と同様の差が認められた. Satisficing 傾向ごとの平均值を Figure 3 に, 箱ひげ図を Figure 4 に示す.

単純主効果の有意性検定については Satsificing 傾向による違いがない一方で, 効果量 $d$ は Complier, Convert, Saitisficerの順に小さくなり, Supermarket story は 1.74, 1.22, 0.72, Traffic ticket story は 1.73, 1.20，0.67であった. 特に Satisficers における効果量は他 2 群と比べて(絶対的には決して小さくはないが) 小さく, Miura \& Kobayashi (2016)が指摘した, Satisficing が実験結果を毀損する可能性と, 注意喚起を行う ことによりそれをより適切な方向に修正できる可能性が, ともに示されたといえる.

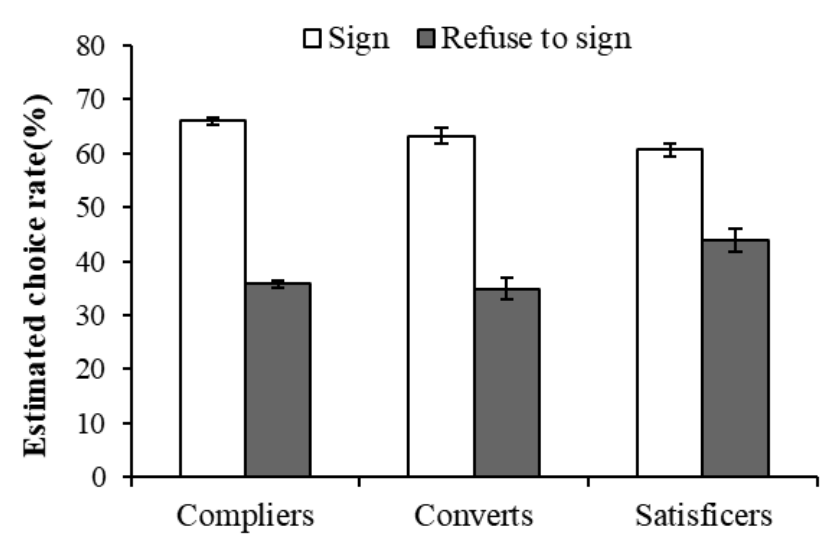

Supermarket story

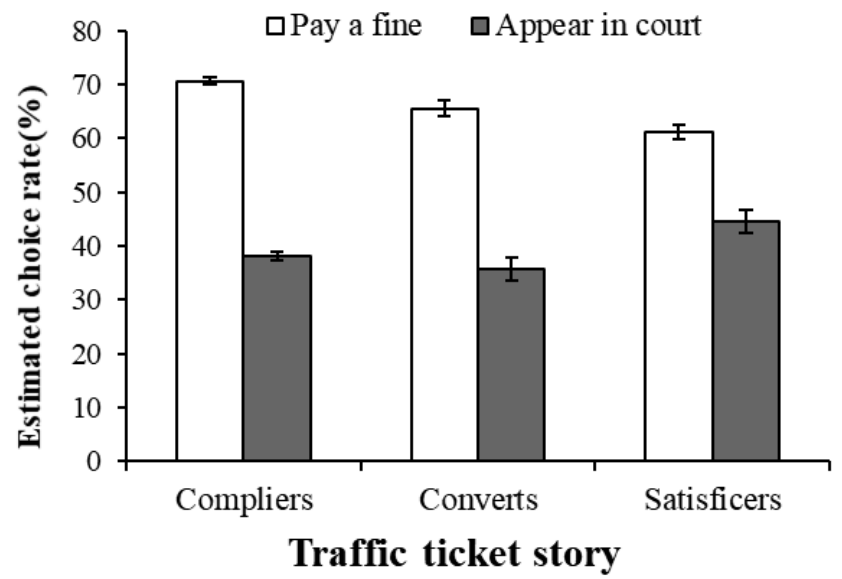


Figure 3 Satisficing 傾向ごとの選択率の推定:平均值(エラーバーは標準誤差)
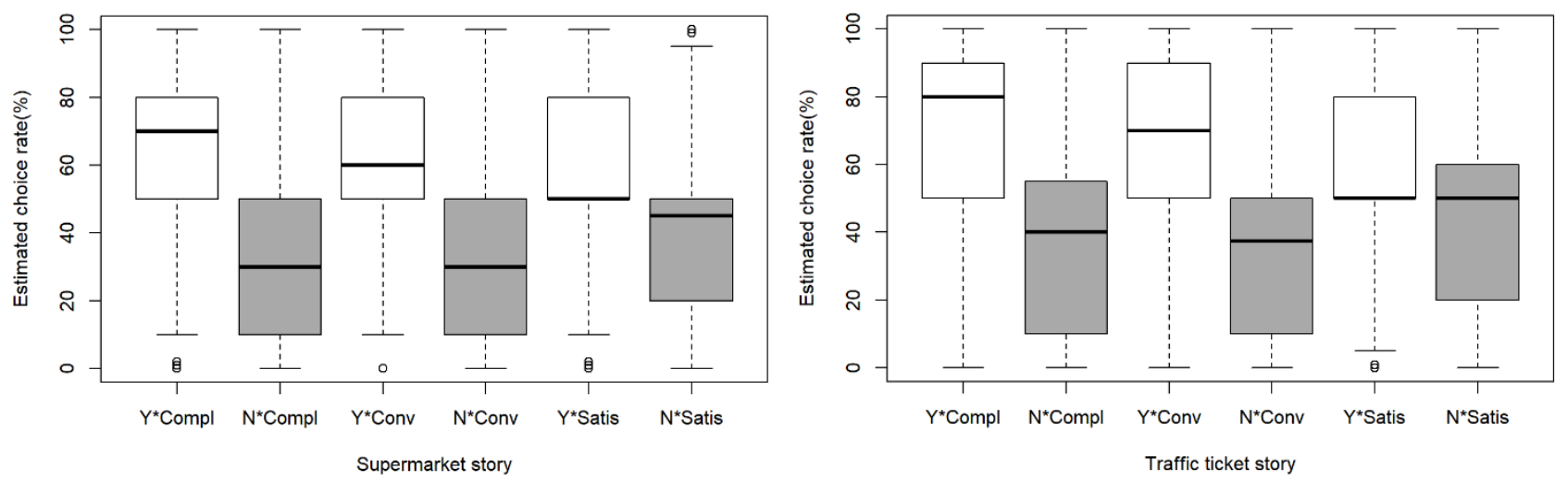

Figure 4 Satisficing 傾向ごとの選択率の推定:箱ひげ図 (Y が「サインする」あるいは「罰金を支払う」)

\section{4 参考 回答者 IP アドレスの検証}

クラウドソーシングサービスを利用した調査実施において今般問題となっていることの 1 つに, VPS(Virtual Private Server)を使った対象国外からのアクセスによる回答がある. Amazon Mechanical Turk では, VPS によって US 限定の調査にUS 外から回答する事例が, 2015 年春頃にはすでに存在し, 2018 年 夏から秋にかけて急増して回答の $20 \%$ 程度を占めるに至っていたといら指摘がある(Kennedy et al., 2020). 対象国を限定して調査を実施する場合，こうした回答は不正となるが，注意確認項目によって取り除くことは 困難である. そこで, US データについて, Qualtrics での回答時に取得した IPアドレスを対象として, Waggoner \& Kennedy, \& Clifford (2019)が提供するオンラインアプリケーション IPlookup (https://rkennedy.shinyapps.io/IPlookup/)を用いて該当するアクセスを検出した. VPS だと判定されたのは 806 件中 1 件であった. このアプリの適用範囲は US に限られているため, 他の対象国の状況は不明だが, 現状では Kennedy et al.(2020)らが指摘するような問題が生じている可能性は低そうである.

\section{4. オープンデータ}

本報告で収集・分析した調査のコードブックおよびデータは https://osf.io/bxtru/からダウンロード可能で ある.

\section{利益相反}

本論文に関して, 開示すべき利益相反関連事項はない.

\section{引用文献}

1) Aronow, P. M., Kalla, J., Orr, L., \& Ternovski, J. (2020, September 15). Evidence of Rising Rates of Inattentiveness on Lucid in 2020. SocArXiv Papers. doi: 10.31235/osf.io/8sbe4

2) Kennedy, R., Clifford, S., Burleigh, T., Waggoner, P. D., Jewell, R., \& Winter, N. J. (2020). The shape of and solutions to the MTurk quality crisis. Political Science Research and Methods, 8(4), 614-629. doi: 10.1017/psrm.2020.6 
3) Klein, R. A., Vianello, M., Hasselman, F., Adams, B. G., Adams Jr, R. B., Alper, S., ... \& Sowden, W. (2018). Many Labs 2: Investigating variation in replicability across samples and settings. Advances in Methods and Practices in Psychological Science, 1(4), 443-490. doi: 10.1177/2515245918810225

4) Krosnick, J. A., Narayan, S., \& Smith, W. R. (1996). Satisficing in surveys: Initial evidence. New Directions for evaluation, 1996(70), 29-44. doi: 10.1002/ev.1033

5) Miura, A., \& Kobayashi, T. (2016). Survey satisficing inflates stereotypical responses in online experiment: The case of immigration study. Frontiers in Psychology, 7, 1563. doi: 10.3389/fpsyg.2016.01563

6) 三浦麻子・小林哲郎 (2016). オンライン調査における努力の最小限化 (Satisfice) 傾向の比較: IMC 違 反率を指標として. 情報・メディア・コミュニケーション研究, 1, 27-42.

7) Miura, A., \& Kobayashi, T. (2019). Survey satisficing biases the estimation of moderation effects. Japanese Psychological Research, 61(3), 204-210. doi: 10.1111/jpr.12223

8) Ross, L., Greene, D., House, P. (1977). The "false consensus effect": An egocentric bias in social perception and attribution processes. Journal of Experimental Social Psychology, 13(3), 279-301. doi:10.1016/0022-1031(77)90049-X

9) Waggoner et al., (2019). Detecting Fraud in Online Surveys by Tracing, Scoring, and Visualizing IP Addresses. Journal of Open Source Software, 4(37), 1285. doi: 10.21105/joss.01285 